\title{
Hindsiipropane B alleviates HIV-1 Tat-induced inflammatory responses by suppressing HDAC6-NADPH oxidase-ROS axis in astrocytes
}

\author{
Hyundong Jo ${ }^{1}$, Ha Young Jang ${ }^{2}$, Gi Soo Youn ${ }^{1}$, Donggyu Kim ${ }^{1}$, Chae Yeon Lee ${ }^{1}$, Jae Hee Jang ${ }^{1}$, Soo Young Choi ${ }^{1}$, \\ Jong-Gab Jun ${ }^{2}$ E Jinseu Park,** \\ ${ }^{1}$ Department of Biomedical Science and Research Institute for Bioscience \& Biotechnology, Hallym University, Chunchon 24252, \\ ${ }^{2}$ Department of Chemistry and Institute of Applied Chemistry, Hallym University, Chunchon 24252, Korea
}

\begin{abstract}
Human immunodeficiency virus-1 (HIV-1) transactivator of transcription (Tat) is an important viral factor in neuroinflammation. Hindsiipropane B, present in Celastrus hindsii, possesses various biological mechanisms including antiinflammatory activity. In this report, we explored the regulatory activity of hindsiipropane B on HIV-1 Tat-mediated chemokine production and its mode of action in astrocytes. Hindsiipropane B significantly alleviated HIV-1 Tat-mediated production of inflammatory chemokines, CCL2, CXCL8, and CXCL10. Hindsiipropane B inhibited expression of HDAC6, which is important regulator in HIV-1 Tat-mediated chemokine production. Hindsiipropane B diminished HIV-1 Tat-mediated reactive oxygen species (ROS) generation and NADPH oxidase activation/expression. Furthermore, hindsiipropane B inhibited HIV-1 Tat-mediated signaling cascades including MAPK, NF-KB, and AP-1. These data suggest that hindsiipropane B exerts its inhibitory effects on HIV-1 Tat-mediated chemokine production via down-regulating the HDAC6-NADPH oxidaseMAPK-NF-KB/AP-1 signaling axis, and could serve as a therapeutic lead compound against HIV-1 Tat-associated neuroinflammation. [BMB Reports 2018; 51(8): 394-399]
\end{abstract}

\section{INTRODUCTION}

Infection of human immunodeficiency virus-1 (HIV-1) induces extensive neuro-inflammation that may contribute to various neurologic dysfunctions, such as HIV-associated encephalitis and dementia. The entry of immune cells including monocytes

${ }^{*}$ Corresponding author. Tel: +82-33-248-2116; Fax: +82-33-2563420; E-mail: jinpark@hallym.ac.kr

https://doi.org/10.5483/BMBRep.2018.51.8.061

Received 23 March 2018, Revised 11 April 2018, Accepted 23 April 2018

Keywords: Chemokines, HDAC6, HIV-1 Tat, Inflammation, NADPH oxidase and T lymphocytes into the central nervous system (CNS) is a characteristic feature of HIV-1-mediated neuro-inflammation (1). CNS infiltration of immune cells is enhanced by several pro-inflammatory mediators including chemokines (2).

HIV-1 trans-activator of transcription (Tat) can up-regulate the expression of various chemokines including CCL2, CXCL8, and CXCL10, in astrocytes $(3,4)$. Up-regulation of these chemokines facilitates the entry of immune cells in the CNS (5). Therefore, HIV-1 Tat is considered to be an important viral protein involved in the development of neuro-inflammation (6).

HIV-1 Tat stimulates several intracellular signaling cascades that then activate transcription factors, resulting in production of pro-inflammatory chemokines. A previous study showed that activation of astrocytes with HIV-1 Tat up-regulated expression of histone deacetylase 6 (HDAC6) (7). Pharmacological and genetic studies revealed that HDAC6 mediated HIV-1 Tat-mediated production of the chemokines CCL2, CXCL8, and CXCL10 in astrocytes (7), indicating that HDAC6 is main regulator of HIV-1 Tat-induced production of inflammatory mediators. HIV-1 Tat also activates Nox2-based NADPH oxidase that generates reactive oxygen species (ROS), contributing to the production of pro-inflammatory chemokines (8). NADPH oxidase contains membrane-bound components (Nox2/gp91 $1^{\text {phox }}$ and $\mathrm{p} 22^{\text {phox }}$ ) and cytosolic components (small GTPase Rac, $\mathrm{p} 40^{\text {phox }}, \mathrm{p} 47^{\text {phox }}, \mathrm{p} 67^{\text {phox }}$ ) (9). We recently demonstrated that regulatory crosstalk between HDAC6 and NADPH oxidase mediated HIV-1 Tat-induced chemokine production (8). In addition, HIV-1 Tat activates redox-sensitive transcription factors including nuclear factor kappa B (NF-KB) and activator protein-1 (AP-1) that contribute to the production of inflammatory mediators (10-12).

Hindsiipropane B, a 1,3-diarylpropane, present in Celastrus hindsii, is one of the bioactive compounds that have been used as traditional Chinese medicine (13). Previous studies have reported that hindsiipropane B and 1,3-diarylpropane analogs exert protective effects on lipopolysaccharide-mediated inflammatory responses in macrophages $(14,15)$. Based on its immunomodulatory activity, this study explored the regulatory

ISSN: 1976-670X (electronic edition)

Copyright (C) 2018 by the The Korean Society for Biochemistry and Molecular Biology

(c) This is an open-access article distributed under the terms of the Creative Commons Attribution Non-Commercial License (http://creativecommons.org/licenses/by-nc/4.0) which permits unrestricted non-commercial use, distribution, and reproduction in any medium, provided the original work is properly cited. 
roles of hindsiipropane B in HIV-1 Tat-mediated proinflammatory responses and its action modes in astrocytes.

In the present study, we show that hindsiipropane B ameliorated production of CCL2, CXCL8 and CXCL10 by blocking the HDAC6-NADPH oxidase-MAPK-NF-KB/AP-1 signaling axis in astrocytes stimulated with HIV-1 Tat. These results suggest that hindsiipropane $B$ could be a therapeutic candidate against HIV-1 Tat-mediated neuro-inflammation.

\section{RESULTS}

\section{Hindsiipropane B inhibits chemokine production in HIV-1 Tat-stimulated astrocytes}

Extracellular HIV-1 Tat has been shown to up-regulate chemokines, such as CCL2, CXCL8, and CXCL10, in astrocytes $(3,4,7)$. To investigate the regulatory effect of hindsiipropane B (Fig. 1A) on HIV-1 Tat-mediated chemokine production, CRT-MG human astroglial cells were incubated with hindsiipropane B at concentrations of 2-10 $\mu \mathrm{M}$ for $1 \mathrm{~h}$ and then followed by stimulation with $50 \mathrm{nM}$ HIV-1 Tat. Hindsiipropane B did not show any cytotoxicity at the concentrations up to $15 \mu \mathrm{M}$ (data not shown). We measured the levels of chemokine mRNA and protein by RT-qPCR and ELISA, respectively. Hindsiipropane $B$ dose-dependently decreased the amounts of CCL2, CXCL8 and CXCL10 mRNA in HIV-1 Tat-treated CRT-MG cells (Fig. 1B). We also observed

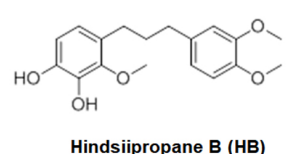

B

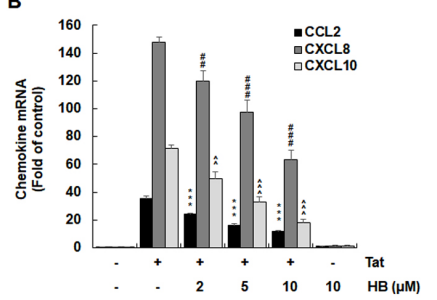

C

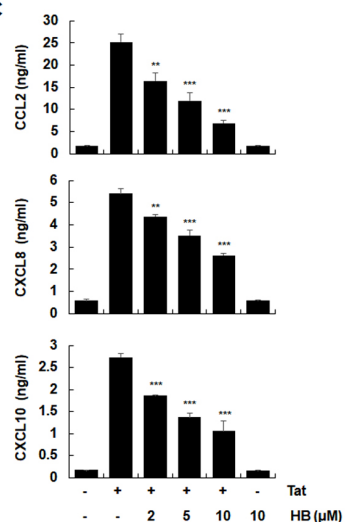

Fig. 1. Effects of hindsiipropane B on HIV-1 Tat-induced chemokine expression in astrocytes. (A) The chemical structure of hindsiipropane B. (B, C) Effects of hindsiipropane B on HIV-1 Tat-mediated expression of CCL2, CXCL8, and CXCL10. CRT-MG cells were pretreated with hindsiipropane $B$ for $1 \mathrm{~h}$ and then exposed to $50 \mathrm{nM}$ HIV-1 Tat for $3 \mathrm{~h}$ (for mRNA expression) or $24 \mathrm{~h}$ (for protein expression). Total RNA was analyzed by quantitative RT-PCR (B). Culture media of cells were collected and assayed for CCL2, CXCL8, and CXCL10 by ELISA (C). Data are shown as mean \pm SD of three independent experiments. ${ }^{*} \mathrm{P}$ $<0.05$, ** $\mathrm{P}<0.01,{ }^{\# \#} \mathrm{P}<0.01$, ${ }^{\# \# \#} \mathrm{P}<0.001$, ${ }^{\wedge} \mathrm{P}<0.01$, and ${ }^{\wedge} \mathrm{P}<0.001$, as compared to the cells treated with HIV-1 Tat alone. $\mathrm{HB}$, hindsiipropane $\mathrm{B}$. that hindsiipropane B decreased the amounts of CCL2, CXCL8 and $\mathrm{CXCL} 10$ proteins in the culture solution of both cells stimulated by HIV-1 Tat (Fig. 1C).

\section{Hindsiipropane B inhibits HDAC6 expression and MAPK activation in HIV-1 Tat-stimulated astrocytes}

HDAC6 expression and MAPK activation have been shown to be crucial for HIV-1 Tat-mediated production of inflammatory chemokines in astrocytes (7). Therefore, we examined the effect of hindsiipropane B on HIV-1 Tat-mediated HDAC6 expression in astrocytes. Hindsiipropane B dose-dependently suppressed HIV-1 Tat-induced mRNA and protein expression of HDAC6 in CRT-MG cells (Fig. 2A and B). Decreased HDAC6 expression was correlated with increased acetylated $\alpha$-tubulin in cells (Fig. 2B).

We next examined the effects of hindsiipropane $B$ on activated ERK, JNK and p38 MAPK in HIV-1 Tat-stimulated astrocytes. HIV-1 Tat increased the phosphorylation levels of ERK, JNK, and p38 MAP kinase (Fig. 2C). Hindsiipropane B dose-dependently inhibited HIV-1 Tat-mediated activation of all three MAPKs (Fig. 2C and D).
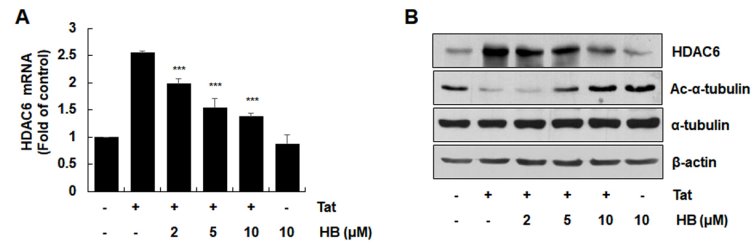

C

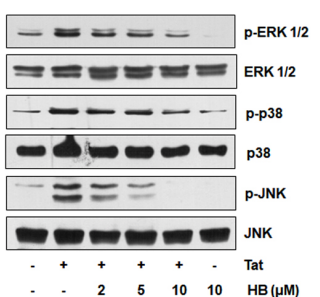

D

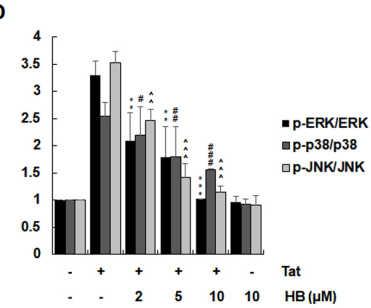

Fig. 2. Effects of hindsiipropane $B$ on HIV-1 Tat-mediated expression of HDAC6 and MAPK activation in astrocytes. CRT-MG cells were pretreated with hindsiipropane $B$ for $1 \mathrm{~h}$ and then exposed to HIV-1 Tat $(50 \mathrm{nM})$. (A) After $3 \mathrm{~h}$, total RNA was harvested and assayed for mRNA expression of HDAC6 and $\beta$-actin by quantitative RT-PCR. (B) After $24 \mathrm{~h}$, cell extracts were collected and evaluated for the levels of HDAC6, acetylated $\alpha$-tubulin, $\alpha$-tubulin and $\beta$-actin by Western blotting. (C) Cells were pretreated with hindsiipropane $\mathrm{B}$ for $1 \mathrm{~h}$ and then stimulated with 50 nM HIV-1 Tat for $1 \mathrm{~h}$. Cell lysates were collected and evaluated for the levels of phosphorylated and total ERK, p38, and JNK by Western blotting using relevant antibodies. (D) The intensity of each MAPK bands were quantified by scanning densitometry and normalized to total MAPK levels. Data are shown as mean $\pm \mathrm{SD}$ of three independent experiments. $* * \mathrm{P}$ $<0.01, * * * \mathrm{P}<0.001,{ }^{\#} \mathrm{P}<0.05,{ }^{\# \#} \mathrm{P}<0.01,{ }^{\# \#} \mathrm{P}<0.001$, $\wedge^{\wedge} \mathrm{P}<0.01$, and ${ }^{\wedge} \mathrm{P}<0.001$, as compared to the cells treated with HIV-1 Tat alone. 


\section{Hindsiipropane B inhibits HIV-1 Tat-mediated NADPH oxidase activation and ROS generation in astrocytes} Since Nox2-based NADPH oxidase is a critical enzyme complex for HIV-1 Tat-mediated ROS generation responsible for up-regulation of pro-inflammatory factors in astrocytes (12), we analyzed the effects of hindsiipropane B on HIV-1 Tat-mediated ROS generation and NADPH oxidase activation in astrocytes. Hindsiipropane B reduced HIV-1 Tat-induced ROS generation, as judged by DHE staining (Fig. 3A). We then evaluated the effect of hindsiipropane B on HIV-1 Tat-mediated $\mathrm{NADPH}$ oxidase activity and found that it significantly suppressed this activity (Fig. 3B). In addition, hindsiipropane B decreased the level of $\mathrm{p} 47^{\text {phox }}$ associated with gp9 ${ }^{\text {phox }} /$ Nox2 in a co-immunoprecipitation experiment (Fig. 3C). We further analyzed the effect of hindsiipropane B on HIV Tat-mediated expression of NADPH oxidase subunits. Hindsiipropane $B$ dose-dependently decreased HIV-1 Tat-induced mRNA expression of gp91 $1^{\text {phox }} /$ Nox 2, p $47^{\text {phox }}$ and p22 $2^{\text {phox }}$ (Fig. 3D).
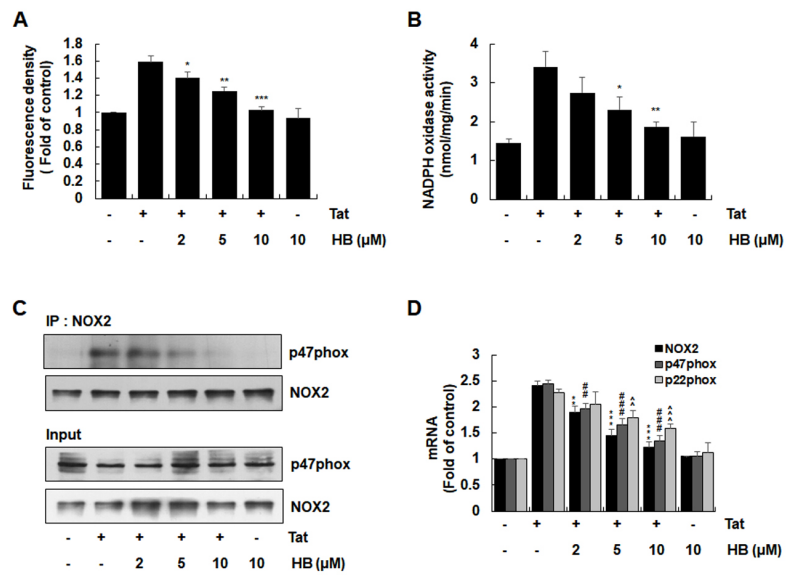

Fig. 3. Effects of hindsiipropane $B$ on HIV-1 Tat-mediated ROS generation and NADPH oxidase activation in CRT-MG cells. (A) Cells were pretreated with hindsiipropane $B$ for $1 \mathrm{~h}$ and then stimulated with $50 \mathrm{nM}$ HIV-1 Tat for $1 \mathrm{~h}$. Cells were stained with DHE for $30 \mathrm{~min}$. The levels of intracellular ROS probed with DHE were evaluated using an ELISA plate reader. (B) Cells pretreated with hindsiipropane $B$ for $1 \mathrm{~h}$ were exposed to $50 \mathrm{nM}$ HIV-1 Tat for $1 \mathrm{~h}$. Cells were collected and mixed with $250 \mu \mathrm{M}$ $\mathrm{NADPH}$. NADPH depletion was observed by measuring reduction in absorbance at $\lambda=340$ for $10 \mathrm{~min}$. (C) Cells pretreated with hindsiipropane $B$ for $1 \mathrm{~h}$ were exposed to $50 \mathrm{nM} \mathrm{HIV-1}$ Tat for 1 h. Cell lysates were collected and immune-precipitated with gp91phox/NOX2 antibody, followed by Western blotting using a p47phox antibody to determine the levels of p47phox associated with gp91phox/NOX2. (D) Cells pretreated with hindsiipropane B for $1 \mathrm{~h}$ were stimulated with $50 \mathrm{nM}$ HIV-1 Tat for $3 \mathrm{~h}$. Total RNA was collected and assayed for mRNA levels of gp91phox/NOX2, p47phox, p22phox, and $\beta$-actin by quantitative RT-PCR. Data are shown as mean \pm SD of three independent experiments. ${ }^{*} \mathrm{P}<0.05, * * \mathrm{P}<0.01,{ }^{*} * \mathrm{P}<0.001$, ${ }^{\# \#} \mathrm{P}<$ 0.01, ${ }^{\# \# \# P} \mathrm{P}$ 0.001, ^^P $<0.01$, and ^^^P $<0.001$, as compared to the cells treated with HIV-1 Tat alone.

\section{Hindsiipropane B inhibits HIV-1 Tat-mediated activation of NF- $\mathrm{KB}$ and AP-1 in astrocytes}

Both NF-KB and AP-1 signaling cascades contribute to the production of pro-inflammatory chemokines on stimulation with HIV-1 Tat $(4,10-12)$. We examined the effects of hindsiipropane $B$ on the signaling cascades responsible for $\mathrm{NF}-\mathrm{KB}$ and $\mathrm{AP}-1$ activation. Hindsiipropane $\mathrm{B}$ reduced NF- $\mathrm{KB}$ p65 phosphorylation and restored IKB $\alpha$ degradation in HIV-1 Tat-treated cells (Fig. 4A). We also observed that hindsiipropane $B$ decreased p65 translocation into the nucleus in HIV-1 Tat-stimulated cells (Fig. 4A). Similarly, hindsiipropane B alleviated HIV-1 Tat-mediated c-Jun phosphorylation as well as $\mathrm{c}$-jun/c-fos translocation into the nucleus (Fig. 4C). We next evaluated the effect of hindsiipropane $B$ on DNA binding activity of NF-KB and AP-1 subunit using EMSA. Hindsiipropane $B$ reduced HIV-1 Tat-mediated NF-KB and AP-1 DNA binding activities (Fig. 4B and D).

\section{DISCUSSION}

The recruitment and retention of immune cells into the CNS, an important step in neuro-inflammation, are regulated by various pro-inflammatory mediators including adhesion molecules, cytokines and chemokines. Therefore, proinflammatory mediator inhibition in the CNS may be a target in screening therapeutic compounds against neuro-
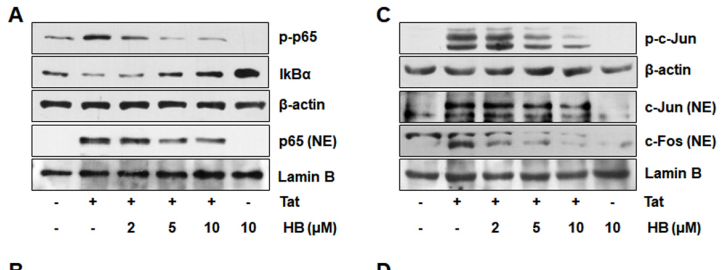

B $\begin{array}{ccccc}+ & + & + & - & \text { Tat } \\ 2 & 5 & 10 & 10 & \text { HB (HM } \\ & & & & \end{array}$

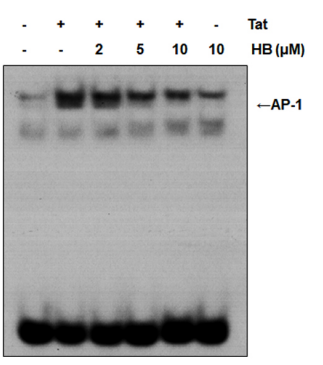

Fig. 4. Effects of hindsiipropane $B$ on NF-kB and AP-1 signaling cascades in HIV-1 Tat-stimulated CRT-MG cells. Cells were pretreated with hindsiipropane B for $1 \mathrm{~h}$ and then stimulated with $50 \mathrm{nM}$ HIV-1 Tat for $1 \mathrm{~h}$. Whole cell or nuclear extracts were collected and assayed for p65 and $\operatorname{I\kappa B} \alpha(\mathrm{A})$ or c-Jun and c-Fos (C) by Western blotting using relevant antibodies. (A) Cell lysates were collected. The amount of phosphorylated p65 and $1 \kappa \mathrm{B} \alpha$ in the cell lysates, as well as p65 in the nuclear extracts, was measured by Western blotting. (B, D) Nuclear extracts from HIV-1 Tat-stimulated cells were collected and assayed for DNA binding activity of NF-KB and AP-1 by EMSA. 
inflammation. Hindsiipropane B, a 1,3-diarylpropane, has been shown to down-regulate expression of inflammatory factors, such as COX-2 and iNOS, by suppressing MAPK and NF-KB signaling cascades $(14,15)$. However, the action modes by which hindsiipropane $B$ exerts anti-inflammatory activity have not yet elucidated. In this study, we demonstrated that hindsiipropane B ameliorated HIV-1 Tat-induced CCL2, CXCL8 and CXCL10 expression by suppressing the HDAC6NADPH oxidase-ROS-MAPK-NF-kB/AP-1 axis in astrocytes.

Astrocytes are major players in mediating the inflammatory process by expressing various pro-inflammatory chemokines that regulate the recruitment and retention of immune cells into the CNS. HIV-1 Tat induces abnormal expression of various chemokines, such as CCL2, CXCL8, and CXCL10, that may facilitate the pathologic process during HIV-related neurological disorder $(16,17)$. Hindsiipropane B significantly suppressed HIV-1 Tat-mediated production of CCL2, CXCL8, and CXCL10 by decreasing their mRNA levels in CRT-MG cells and mouse primary astrocytes (data not shown), indicating its anti-inflammatory activity in HIV-1 Tat-treated astrocytes.

HDAC6 expression has been shown to be a key player in production of pro-inflammatory mediators including chemokines $(7,18)$. Consequently, HDAC6 is considered to be a pivotal target in HIV-1 Tat-mediated neuro-inflammation. Our previous studies elucidated that HIV-1 Tat enhanced HDAC6 expression that was critical for HIV-1 Tat-induced production of CCL2, CXCL8, and CXCL10 in astrocytes $(7,8)$ and the contribution of HDAC6 to HIV-1 Tat-mediated production of pro-inflammatory chemokines was confirmed by genetic and pharmacological studies (7). Recent experiments using overexpression of HDAC6 demonstrated the involvement of HDAC6 in pro-inflammatory cytokine expression in macrophages (18). Consistent with these results, hindsiipropane B suppressed HIV-1 Tat-induced HDAC6 expression, concomitant with increased acetylated $\alpha$-tubulin in astrocytes. These results indicate that hindsiipropane B down-regulates CCL2, CXCL8, and CXCL10 expression by suppressing HDAC6 expression in astrocytes.

NADPH oxidase-derived ROS participates in activating various signal transduction processes in astrocytes (19-21). HIV-1 Tat has been demonstrated to be capable of activating Nox2-based NADPH oxidase, leading to ROS generation that is responsible for pro-inflammatory chemokine expression (8, 12). In addition, HIV-1 Tat increases the expression of NADPH oxidase subunits, such as gp $91^{\text {phox }} / \mathrm{Nox} 2, \mathrm{p} 47^{\text {phox }}$, and $\mathrm{p} 22^{\text {phox }}$, in astrocytes (8). We observed that hindsiipropane B suppressed HIV-1 Tat-induced Nox2-based NADPH oxidase activity as well as subsequent ROS production. Activation of $\mathrm{NADPH}$ oxidase requires the translocation of the $\mathrm{p} 47^{\text {phox }}$ cytosolic component to the cellular membrane and its interaction with gp91 $1^{\text {phox }} /$ Nox2 (9). Hindsiipropane B decreased the level of $\mathrm{p} 47^{\text {phox }}$ associated with $\mathrm{gp} 91^{\text {phox }} /$ Nox2 in a co-immunoprecipitation experiment. In addition, hindsiipropane
B down-regulated HIV-1 Tat-induced expression of gp91 ${ }^{\text {phox }} /$ Nox2, $\mathrm{p} 47^{\text {phox }}$, and $\mathrm{p} 22^{\text {phox }}$. All together, these results point out that hindsiipropane B decreases HIV-1 Tat-mediated ROS generation by suppressing Nox2-based NADPH oxidase activity and expression in astrocytes.

Stimulating astrocytes with HIV-1 Tat initiates activation of MAPK signaling cascades in which ERK, JNK, and p38 are phosphorylated, and they participate in the production of pro-inflammatory mediators $(22,23)$; hindsiipropane B decreased HIV-1 Tat-mediated activation of all three MAPKs. Although the exact roles of the different MAPKs have not been explored in HIV-1 Tat-mediated pro-inflammatory chemokine expression, all three MAPKs participate in NF-KB activation in HIV-1 Tat-stimulated human astrocytes $(4,10)$. JNK is known to contribute to AP-1 activation in astrocytes.

Because activation of NF-KB and/or AP-1 contributes to HIV-1 Tat-mediated chemokine expression $(10,12)$, we next performed experiments to evaluate the effects of hindsiipropane $\mathrm{B}$ on NF-KB and AP-1 signaling cascades. Hindsiipropane B suppressed the NF-KB signaling axis including IKK phosphorylation, I $\mathrm{\kappa} \mathrm{B} \alpha$ degradation and $\mathrm{p} 65$ phosphorylation/nuclear localization in HIV-1 Tat-treated astrocytes. A previous study suggested that hindsiipropane $B$ exerted its anti-inflammatory effects by down-regulating LPS-induced NF-KB activation (15). Consistent with these results, hindsiipropane $B$ inhibited NF- $\kappa B$ activation in HIV-1 Tat-stimulated cells. Hindsiipropane $\mathrm{B}$ also diminished HIV-1 Tat-mediated c-jun phosphorylation, c-jun/c-fos nuclear localization, and AP-1 promoter activity. These results collectively point out that hindsiipropane B exerts its anti-inflammatory effects by inhibiting MAPKNF-KB/AP-1 signaling axis in HIV-1 Tat-treated astrocytes.

In conclusion, our study provide evidences that hindsiipropane $B$ exerts suppressive activity on production of pro-inflammatory chemokines, such as CCL2, CXCL8, and CXCL10, in HIV-1 Tat-treated astrocytes. This anti-inflammatory activity is mediated by suppressing HDAC6-NADPH oxidaseROS-MAPK-NF-KB/AP-1 axis in astrocytes. Elucidating the action mechanisms by which hindsiipropane $B$ down-regulates pro-inflammatory mediators may lead to developing therapeutic agents against HIV-1 Tat-related neuro-inflammation.

\section{MATERIALS AND METHODS}

\section{Reagents}

Primary antibodies against gp91phox/NOX2, p47phox, acetylated $\alpha$-tubulin, p65, IkB, c-fos, and c-jun were obtained from Santa Cruz Biotechnology (Santa Cruz, CA, USA). Total-ERK, total-p38, total-JNK, phosphor-ERK, phosphor-p38, phosphor-JNK, $\beta$-actin, and HDAC6 were purchased from Cell Signaling Technology (Beverly, MA, U.S.A.). Hindsiipropane B was synthesized from commercially available starting materials with the Wittig-Horner reaction, Claisen-Schmidt condensation and hydrogenation as key steps (14). $10 \mathrm{mM}$ stock solution of hindsiipropane B was prepared in dimethyl sulfoxide. 
Oligonucleotide primers (HDAC6, CCL2, CXCL8, CXCL10, Nox2, p22phox, p47phox, and $\beta$-actin) (Bioneer, Seoul, Korea) were obtained from commercially.

\section{Cell culture}

An human astroglial cell line CRT-MG was grown in RPMI 1640 medium containing $10 \%$ fetal bovine serum, L-glutamine $(2 \mathrm{mM})$, streptomycin $(100 \mu \mathrm{g} / \mathrm{ml})$, and penicillin $\mathrm{G}(100 \mathrm{U} / \mathrm{ml})$ at $37^{\circ} \mathrm{C}$ in a humidified air supplemented with $5 \% \mathrm{CO}_{2}(24)$.

\section{Preparation of HIV-1 Tat Protein}

Glutathione S-transferase (GST)-Tat fusion protein was expressed from the GST-Tat 1 86R plasmid obtained from the National Institutes of Health AIDS Research and Reference Reagent Program (Rockville, MD, USA). Purified GST-Tat fusion protein was digested with thrombin to get HIV-1 Tat protein as described previously (25). The endotoxin amount in the HIV-1 Tat preparation were below $0.3 \mathrm{EU} / \mathrm{ml}$ as determined by a Limulus Amoebocyte Lysate assay (BioWhitaker, Walkersville, MD, USA).

\section{Western blot analysis}

Cells were lysed using a buffer containing $125 \mathrm{mM}$ Tris- $\mathrm{HCl}$ $\mathrm{pH} 6.8,2 \% \mathrm{SDS}, 10 \% \mathrm{v} / \mathrm{v}$ glycerol. The protein concentrations of the cell lysates were assessed by Bradford protein assay (Bio-Rad, Hercules, CA, USA). Thirty micrograms of proteins were separated on 10\% SDS-PAGE, and transferred to nitrocellulose membranes. The blots were probed with the primary antibody against the target protein at $4^{\circ} \mathrm{C}$ overnight, followed by incubation with the horseradish peroxidase (HRP)-conjugated secondary antibody (1:10,000 dilution) for 2 $\mathrm{h}$ at room temperature. The antibody-reactive bands were visualized by a chemiluminescence kit (Amersham Life Sciences, Parsippany, NJ, USA) (26).

\section{Real-time Reverse Transcription-Polymerase Chain Reaction (RT-PCR) analysis}

Total cellular RNA was prepared using a Trizol reagent kit (Invirogen, Gaithersburg, MD, USA). Two micrograms of total RNA were reverse-transcribed into cDNA using 10,000 $U$ of reverse transcriptase and $0.5 \mu \mathrm{g} / \mu \mathrm{l}$ oligo-(dT) 15 primer (Promega) (8). The resulting CDNA was analyzed by quantitative PCR using $\mathrm{iQ}^{\mathrm{TM}}$ SYBR $^{\mathbb{R}}$ Green Supermix (BIO-RAD, Hercules, CA, USA) with the primer sets described previously (8).

\section{Enzyme-Linked Immunosorbent Assay (ELISA)}

Culture media were harvested and analyzed for the levels of chemokines (CCL2, CXCL8, and CXCL10) by ELISA kits (R\&D Systems, Minneapolis, MN, USA), according to the manufacturer's instructions.

\section{Assessment of Intracellular ROS Generation}

Intracellular ROS levels were determined by a dihydroethidium (DHE) assay as described previously (8). DHE is converted by superoxide into red fluorescent ethidium. The intensity of cellular fluorescence for DHE was determined at $590 \mathrm{~nm}$ excitation and $650 \mathrm{~nm}$ emission using a SpectraMax M2 ELISA plate reader (Molecular Devices, Sunnyvale, CA, USA).

\section{Measurement of NADPH Oxidase Activity}

Cells collected from 6 wells-plates were re-suspended in phosphate buffered saline. The enzymatic activity of NADPH oxidase in the samples was determined as described previously (12).

\section{Detection of $\mathrm{p} 47^{\text {phox }}$ Association with gp91 ${ }^{\text {phox }}$}

The levels of $\mathrm{p} 47^{\text {phox }}$ associated with gp9 $1^{\text {phox }}$ were assessed by co-immunoprecipitation followed by Western blot analysis as described previously (8). Briefly, cells were incubated with a lysis buffer consisting of $50 \mathrm{mM}$ HEPES (pH 7.5), $150 \mathrm{mM}$ $\mathrm{NaCl}, 2 \mathrm{mM}$ EDTA, $0.5 \% \mathrm{NP}-40$, 5\% glycerol, and complete mini protease inhibitor cocktail (Roche Diagnostics, Indianapolis, IN, USA). The clarified cellular lysates were reacted with anti-gp91 $1^{\text {phox }}$ antibody at $4^{\circ} \mathrm{C}$ overnight on a rotating shaker. Immune complexes were collected by protein A/G-agarose beads (Santa Cruz Biotechnology, Dallas, TX, USA). Aliquots of immune-precipitates were separated on $10 \%$ SDS-PAGE and analyzed by Western blotting using an anti-p $47^{\text {phox }}$ antibody described above.

\section{Electrophoretic Mobility Shift Assay (EMSA)}

Cells were pretreated with hindsiipropane B for $1 \mathrm{~h}$, followed by stimulation with HIV-1 Tat $(50 \mathrm{nM})$ for $1 \mathrm{~h}$. Nuclear extracts of cells were analyzed for NF-KB or AP-1 binding activity by EMSA as described previously (27).

\section{Statistical analysis}

Results are presented as the mean \pm standard deviation (SD) from three independent experiments. Statistical analysis was performed by one-way analysis of variance, followed by Bonferroni's test using SigmaPlot 10.0 software (SYSTAT Software Inc, Chicago, IL, USA). Differences were considered significant at $\mathrm{P}<0.05$.

\section{ACKNOWLEDGEMENTS}

This study was funded by a Basic Science Research Program Grant (2015R1D1A1A01060275) and by a Priority Research Centers Program Grant (2009-0093812) through the National Research Foundation of Korea, funded by the Ministry of Education. This research was also supported by a grant (HRF-201706-008) from Hallym University.

\section{CONFLICTS OF INTEREST}

The authors have no conflicting interests. 


\section{REFERENCES}

1. Yao H, Bethel-Brown C, Li CZ and Buch SJ (2010) HIV neuropathogenesis: a tight rope walk of innate immunity. J Neuroimmune Pharmacol 5, 489-495

2. Ozdener H (2005) Molecular mechanisms of HIV-1 associated neurodegeneration. J Biosci 30, 391-405

3. Nookala AR and Kumar A (2014) Molecular mechanisms involved in HIV-1 Tat-mediated induction of IL-6 and IL-8 in astrocytes. J Neuroinflammation 11, 214

4. Youn GS, Kwon DJ, Ju SM et al (2014) Celastrol ameliorates HIV-1 Tat-induced inflammatory responses via NF-kappaB and AP-1 inhibition and heme oxygenase-1 induction in astrocytes. Toxicol Appl Pharmacol 280, 42-52

5. Farina C, Aloisi F and Meinl E (2007) Astrocytes are active players in cerebral innate immunity. Trends Immunol 28, 138-145

6. Bagashev A and Sawaya BE (2013) Roles and functions of HIV-1 Tat protein in the CNS: an overview. Virol J 10, 358

7. Youn GS, Ju SM, Choi SY and Park J (2015) HDAC6 mediates HIV-1 tat-induced proinflammatory responses by regulating MAPK-NF-kappaB/AP-1 pathways in astrocytes. Glia 63, 1953-1965

8. Youn GS, Cho H, Kim D, Choi SY and Park J (2017) Crosstalk between HDAC6 and Nox2-based NADPH oxidase mediates HIV-1 Tat-induced pro-inflammatory responses in astrocytes. Redox Biol 12, 978-986

9. Lambeth JD, Kawahara T and Diebold B (2007) Regulation of Nox and Duox enzymatic activity and expression. Free Radic Biol Med 43, 319-331

10. Bruce-Keller AJ, Barger SW, Moss NI, Pham JT, Keller JN and Nath A (2001) Pro-inflammatory and pro-oxidant properties of the HIV protein Tat in a microglial cell line: attenuation by 17 beta-estradiol. J Neurochem 78, 1315-1324

11. Lim SP and Garzino-Demo A (2000) The human immunodeficiency virus type 1 Tat protein up-regulates the promoter activity of the beta-chemokine monocyte chemoattractant protein 1 in the human astrocytoma cell line U-87 MG: role of SP-1, AP-1, and NF-kappaB consensus sites. J Virol 74, 1632-1640

12. Song HY, Ju SM, Seo WY et al (2011) Nox2-based NADPH oxidase mediates HIV-1 Tat-induced up-regulation of VCAM-1/ICAM- 1 and subsequent monocyte adhesion in human astrocytes. Free Radic Biol Med 50, 576-584

13. Hu XQ, Han W, Han ZZ et al (2014) Three new diphenylpropanes from Celastrus hindsii. Arch Pharm Res 37, 1411-1415

14. Jang HY, Park HJ, Damodar K, Kim JK and Jun JG (2016) Dihydrostilbenes and diarylpropanes: Synthesis and in vitro pharmacological evaluation as potent nitric oxide production inhibition agents. Bioorg Med Chem Lett 26, 5438-5443

15. Vijaya Bhaskar Reddy M, Hung HY, Kuo PC et al (2017) Synthesis and biological evaluation of chalcone, dihydrochalcone, and 1,3-diarylpropane analogs as antiinflammatory agents. Bioorg Med Chem Lett 27, 1547-1550

16. Li JC, Yim HC and Lau AS (2010) Role of HIV-1 Tat in AIDS pathogenesis: its effects on cytokine dysregulation and contributions to the pathogenesis of opportunistic infection. AIDS 24, 1609-1623

17. Rappaport J, Joseph J, Croul S et al (1999) Molecular pathway involved in HIV-1-induced CNS pathology: role of viral regulatory protein, Tat. J Leukoc Biol 65, 458-465

18. Youn GS, Lee KW, Choi SY and Park J (2016) Overexpression of HDAC6 induces pro-inflammatory responses by regulating ROS-MAPK-NF-kappaB/AP-1 signaling pathways in macrophages. Free Radic Biol Med 97, 14-23

19. Abramov AY, Jacobson J, Wientjes F, Hothersall J, Canevari L and Duchen MR (2005) Expression and modulation of an NADPH oxidase in mammalian astrocytes. J Neurosci 25, 9176-9184

20. Brown DI and Griendling KK (2009) Nox proteins in signal transduction. Free Radic Biol Med 47, 1239-1253

21. Gloire G, Legrand-Poels S and Piette J (2006) NF-kappaB activation by reactive oxygen species: fifteen years later. Biochem Pharmacol 72, 1493-1505

22. Ju SM, Song HY, Lee JA, Lee SJ, Choi SY and Park J (2009) Extracellular HIV-1 Tat up-regulates expression of matrix metalloproteinase-9 via a MAPK-NF-kappaB dependent pathway in human astrocytes. Exp Mol Med 41, 86-93

23. Kutsch O, Oh J, Nath A and Benveniste EN (2000) Induction of the chemokines interleukin-8 and IP-10 by human immunodeficiency virus type 1 tat in astrocytes. J Virol 74, 9214-9221

24. An SY, Youn GS, Kim H, Choi SY and Park J (2017) Celastrol suppresses expression of adhesion molecules and chemokines by inhibiting JNK-STAT1/NF-kappaB activation in poly(l:C)-stimulated astrocytes. BMB Rep 50, 25-30

25. Herrmann $\mathrm{CH}$ and Rice AP (1993) Specific interaction of the human immunodeficiency virus Tat proteins with a cellular protein kinase. Virology 197, 601-608

26. Jo HS, Eum WS, Park EY et al (2017) Effects of PEP-1-FK506BP on cyst formation in polycystic kidney disease. BMB Rep 50, 460-465

27. Peng Y, Zhong Y and Li G (2016) Tubeimoside-1 suppresses breast cancer metastasis through downregulation of CXCR4 chemokine receptor expression. BMB Rep 49, $502-507$ 